The Law of Blood 



\title{
The Law of Blood
}

\section{Thinking and Acting as a Nazi}

\author{
Johann Chapoutot
}

Translated by Miranda Richmond Mouillot

The Belknap Press of Harvard University Press CAMBRidge, MASSACHUSETtS • LONDON, ENGLAND 
Copyright (C) 2018 by the President and Fellows of Harvard College All rights reserved Printed in the United States of America

First Printing

This book was originally published as La loi du sang: Penser et agir en nazi (C) Éditions Gallimard, Paris, 2014

\section{Library of Congress Cataloging-in-Publication Data}

Names: Chapoutot, Johann, author. | Richmond Mouillot, Miranda, translator. Title: The law of blood : thinking and acting as a Nazi / Johann Chapoutot ; translated by Miranda Richmond Mouillot.

Other titles: Loi du sang. English

Description: Cambridge, Massachusetts : The Belknap Press of Harvard University Press, 20I8. |"This book was originally published as La loi du sang: Penser et agir en nazi (C) Éditions Gallimard, Paris, 20I4." | Includes bibliographical references and index.

Identifiers: LCCN 2017039800 | ISBN 9780674660434 (alk. paper)

Subjects: LCSH: National socialism-Historiography. | National socialism-

Moral and ethical aspects. | Antisemitism-Germany-History2oth century. | Germany-Politics and government-I933-I945. Classification: LCC DD256.5 .C547513 2018 | DDC 940.53 / 43-dc23

LC record available at https://lccn.loc.gov/201703980o

Jacket image: Farming Family from Kalenberg, I939, by Alfred Wessel. Property of the Federal Republic of Germany / Bridgeman Images

Jacket design: Graciela Galup 
To Marie Anna -J.C.

To Armand Jacoubovitch - M.R.M. 
